Impact Factor: 4.845(SJIF) Research Journal Of English (RJOE) Vol-5, Issue-2, 2020

www.rjoe.org.in An International Peer-Reviewed English Journal

ISSN: 2456-2696

Indexed in: International Citation Indexing (ICI), International Scientific Indexing

(ISI), Directory of Research Journal Indexing (DRJI) Google Scholar \& Cosmos.

\title{
REALITY AS MORAL DISCOVERY IN THE PLAYS OF GIRISH KARNAD
}

\author{
Rafi Shaik, \\ Acharya Nagarjuna University, Department of English Guntur,India \\ Dr Pankaj Kumar K, \\ Department of English, Acharya Nagarjuna University, India
}

\begin{abstract}
:
India has been a land of articulate feelings, eloquent speeches and diverse manifestations; Indian drama comprises all the three. Kalidas, the indomitable, Bhavbhuti, the unimitable and Keshav, the unforgettable, are a few names that enhance this particular sensibility. As regards Indian English drama, it has assumed mythical stature due to its poor growth, right from its inception, as a sheer legacy to be proud of, K.R.S. Iyengar admits the fact while writing, "Modern Indian dramatic writing in English is neither rich in quantity nor, on the whole, of high quality. Enterprising Indians have for nearly a century occasionally attempted drama in English, but seldom for actual stage production." ${ }^{1}$ Going back to the days of launching of Indian English drama, like other genres, it is also imitative and derivative in nature, including translations from other languages, carrying forward its heritage with alien inculcations. The reality is a moral discovery in the selected plays.
\end{abstract}

Key words: Moral Discovery, reality, launching, poorgrowth, production.

\section{Introduction:}

India has been a land of articulate feelings, eloquent speeches and diverse manifestations; Indian drama comprises all the three. Kalidas, the indomitable, Bhavbhuti, the unimitable and Keshav, the unforgettable, are a few names that enhance this particular sensibility. As regards Indian English drama, it has assumed mythical stature due to its poor growth, right from its inception, as a sheer legacy to be proud of, K.R.S. Iyengar admits the fact while writing, "Modern Indian dramatic writing in English is neither rich in quantity nor, on the whole, of high quality. Enterprising Indians have for nearly a century occasionally attempted drama in English, but seldom for actual stage production." ${ }^{1}$

Going back to the days of launching of Indian English drama, like other genres, it is also imitative and derivative in nature, including translations from other languages, carrying forward its heritage with alien inculcations. Krishna Mohan Banerji is the beginner with his The Persecuted (1831), then came the flow of translations: Michael Madhusudan Dutta's 
Impact Factor: 4.845(SJIF) Research Journal Of English (RJOE) Vol-5, Issue-2, 2020

www.rjoe.org.in An International Peer-Reviewed English Journal

ISSN: 2456-2696

Indexed in: International Citation Indexing (ICI), International Scientific Indexing (ISI), Directory of Research Journal Indexing (DRJI) Google Scholar \& Cosmos.

Ratnavali (1858), Sermista (1859) and Is This Called Civilization (1871) followed the corpus of Tagore, Sri Aurobindo and others modeled after the Elizabethan concept and structure, we may easily diagnose the encounter of two cultures (as in K.M. Banerji's The Persecuted), at times compromise and at present a sort of reconciliation and appetite of creation and urge for performance existed, providing ample scope to a bleak future.

"Drama is composite art in which the written word of the playwright attains complete artistic realization only when it becomes the spoken word of the actor on the stage and through that medium reacts of the mind of the audience".

(Naik, 1984, 151)

With advent of Tagore and Sri Aurobindo, Indian English drama got a new impetus. Though these two great literary figures had great impact of the West, considered as gift of the West, their role in enhancing this particular genre cannot be denied. Tagore has been hailed as 'the father of modern Indian Stagecraft' and his drama,"From eros to cosmos, from the pastoral to the Modern age, from a religious bigotry to social comedy, from entertainment and romantic love to martyrdom...the changing scenarios, but each with a thesis, open or hidden, reveal a complex, evolving mind, a repertoire of versatility and development in theme, treatment as well as choreography far beyond the professional playhouse."3

(Ghosh, 1986, 57)

Indian English drama has not been so fortunate as poetry and fiction in Indian English because drama requires specialized skill and talent in selecting a theme which is presentable on the stage and in picking up a technique which appeals to the audience. According to M.K. Naik and Mokashi Punekar (1977: ix), ${ }^{8}{ }^{8}$ it is a composite aid involving the playwright, the actor and the audience in a commonly shared, and even created, artistic experience." Scene, subject, plot, character, dialogue ${ }^{9}$ and technique have to be appropriate to achieve the desired result.

Language is one of the greatest hurdles in the growth of Indian English drama. The participation of the audience is made possible through the mother tongue than a foreign language. Thus, Indian drama mostly flourished in regional languages. Though some talented writers like Shri Aurobindo, R. Tagore. Harindranath Chattopadhyaya in the past and Badal Sarkar, Vijay Tendulkar. Girish Karnad in the present have enriched Indian English drama through their contributions, there is no proper atmosphere for its happy growth today.

The other reason for the setback of Indian English drama is its inability to plant itself in the Indian ethos. India has been a rich storehouse of myths and legends, of folk tales and customs, of historical events and cultural heritage. Our dramatists ought to have made use of 
Impact Factor: 4.845(SJIF) Research Journal Of English (RJOE) Vol-5, Issue-2, 2020

www.rioe.org.in An International Peer-Reviewed English Journal

ISSN: 2456-2696

Indexed in: International Citation Indexing (ICI), International Scientific Indexing (ISI), Directory of Research Journal Indexing (DRJI) Google Scholar \& Cosmos.

them in their creative writings. But, unfortunately, most of them have failed to do so. But. dramatists of today like Girish Karnad has skillfully employed and his plays in order to "interpret contemporary social and political situations"10, as Satish Kumar (1993: 2) observes. Karnad's Tughlaq and Hayavadana are the best examples of it.

Another reason for the setback unsuitability on the stage. That's why, it has suffered greatly in theatrical effects. In this connection K.R.S. Iyengar (1984: 226) remarks: -"Modern Indian dramatic writing in English is neither rich in quantity nor on the whole of. high quality. Enterprising Indians have for nearly a century occasionally attempted drama in English - but seldom for actual stage production." Finally, because of the writers like Badal Sarkar and Girish Karnad contemporary Indian English drama is getting richer with innovative themes and techniques.

Girish Karnad, an actor, a film producer and a TV artiste is regarded as a very significant playwright of the post-independent Indian literature. He is one of the most prolific writers of modern Indo-Anglian drama. He has. so far, written over eight plays, three of which into English. His plays are as folio Tughlaq (1964), Hayavadana (1975), HiltinaHunja, Anju Maltige, Agni Mallu Male (1984), Nagamandala (1990). Thaledanda. (1994) etc.

Girish Karnad'sHayavadana (1975) a play in two acts, is his third play. Originally written in Kannada, the play was an immediate success on the stage and received the prestigious Kamala Devi Chattopadhyaya award of 1971. Like Samuel Beckett translating his own play from French into English 'En Attendant Godot Waiting for Godot', Girish Karnad, also inspired by the success of his play, translated it into English retaining, however, the original title. Hayavadana. Originally published in Enact, it was published b Oxford University Press in 1975 in the New Drama in India Series, and since then it has been performed in different translations and adaptations around the world with great success. Karnad. like T.S. Eliot, follows the sense of history and tradition in Hayavadana $\mathrm{He}$ was highly influenced by the trends in Kannada literature and he took y, tradition and myth lor the plots of his plays like Tughlaq. Hayavadana respectively.

The entire play is cast in the form of traditional Indian folk drama which took several features of ancient Sanskrit drama. Karnad uses the conventions and motifs of folk tales and folk theatre in it. In the treatment of its theme and in the use of stage conventions, Karnad uses the literary and theatrical traditions of the East and the West. The pooja and prayer of Lord Ganesha in the beginning of the play, the role of Bhagavata as a controller of the play's movement and as narrator and occasional interpreter and the use of "Yakshagana" curtains are some Indian traditions. 'Yakshagana' is a special feature of the folkdance drama of coastal Karnataka. 
Impact Factor: 4.845(SJIF) Research Journal Of English (RJOE) Vol-5, Issue-2, 2020

www.rjoe.org.in An International Peer-Reviewed English Journal

ISSN: 2456-2696

Indexed in: International Citation Indexing (ICI), International Scientific Indexing (ISI), Directory of Research Journal Indexing (DRJI) Google Scholar \& Cosmos.

While writing the play. Karnad uses the folk fonn and assimilates into it the tradition of Indian classical drama, the western dramatic conventions to convey his perception of contemporary reality. The play opens with the offering of worship accompanied by singing to the Lord Ganesha. This is perfectly in keeping with the Indian classical tradition, where in the beginning of a drama some god or goddess is invoked for blessing. In 'Yakshagana', it is Lord Ganesha, the god of success that is invoked. At the beginning of the perfonnance a mask of Ganesha is brought on the stage and kept on the chair. In the pooja and prayer, Lord Ganesha is addressed as 'single tasked destroyer of incompleteness' (p. 73). Here, the choice of the elephant-headed god is significant because Lord Ganesha with human body and animal head properly suggests the central theme of incompleteness of being. Lord Ganesha is worshipped as the "destroyer of incompleteness." Bhagavata rightly comments: "An elephant body, a broken tusk and a cracked belly-whichever way you look at it he seems to be an embodiment of imperfection of incompleteness" (p. 73). By invoking the Lord Ganesha and its myth Karnad reconciles the tradition and modernity into a harmonious whole.

Bhagavata, who introduces the story is the stage manager of the classical Sanskrit drama. By using Bhagavata and the kind of role which Karnad assigns to the Bhagavata far outgrows the traditional role. However, in keeping with the folk tradition he narrates the story in the manner of a folk tale: "Our duty is irterely to pay homage to the elephant-headed god and get on with the play" (p. 73) and he begins: "This is the city of Dharmpura. ruled by King Dharmasheela whose fame and empire have already reached the ends of the eight directions" (p. 73). Bhagavata takes charge of the play's opening when the Nata frightened by a speaking Hayavadana. creates a disturbance on the stage. He also decides the time when the half-curtain must be brought in or withdrawn. He initiates the discussion and invites responses to the actions of the characters. He is involved intimately with every character. He expresses sympathy for Kapila when he is forsaken by Devadatta and Pad mini after the transposition.

When Padmini transposes-rfJe heads there is a problem of identity. Bhaeavata solves this problem by the Rishi's verdict. He suggests Hayavadana to go to the temple of Kali at Chitrakoot. Thus, the role of Bhagavata is of a helper, a part-narrator, commentator and an interpreter of the events. The play opens with Bhagavata's prayer of Lord Ganesha and ends with his praise of Lord Ganesha. He says that the mercy of the Elephant-headed Ganesha is unfathomable. Finally, there is a chorus prayer. 'Grant us O Lord, good rains, good crop, prosperity in poetry, science, industry" (p. 75). Bhagavata remains on the stage practically all the time and control the action in a significant way. It is said that Bhagavata becomes a Brcchtian type of narrator. His role as a link between the actors and the audience and the characters is as a mediator.

The other important device drawn from the folk theatre tradition is the use of halfcurtain. Half-curtain is used throughout the play as a very important stage property. While 
Impact Factor: 4.845(SJIF) Research Journal Of English (RJOE) Vol-5, Issue-2, 2020

www.rjoe.org.in An International Peer-Reviewed English Journal

ISSN: 2456-2696

Indexed in: International Citation Indexing (ICI), International Scientific Indexing (ISI), Directory of Research Journal Indexing (DRJI) Google Scholar \& Cosmos.

using the folk strategy of half-curtain, Karnadmodernisesit by giving it a symbolic significance. While dealing with complex states of minds, the half-curtain comes in very handy. ${ }^{12}$

We have already pointed that Karnad uses mask in the play which is the characteristic feature of Indian folk theatre. The first mask to be used is that of Ganesha, the destroyer of obstacles. Later Devadatta in the opening of the play appears on the stage wearing a pale coloured mask and Kapila a dark mask. Later in the play, masks are transposed to indicate the transposition of heads. Kali, the goddess, appears in a terrible mask and Hayavadana appears at first wearing the mask of a horse's head and later when he becomes a complete horse, he wears the mask of a complete horse.

Christopher Caudwell once said (30) that since "man's emotions are fluid and confusing, it would be unsafe to predict about human behaviour"13. What may only be vouchsafed is that every human being nurtures fantasy and the fantasies that myths project reflect both individual and social preoccupations. To that extent at any rate, fantasy expresses a social truth born of 'associated experience' ${ }^{14}$ or what is designated as 'the Collective Unconscious'. In short, the 'truth' contained in the myths is dependent not necessarily upon physical reality but on a psychic one. Hence, now and then, literary artists take recourse to myths to focus upon certain instinctual human drives, irrespective of their morality.

Because a playwright is primarily a communicator, his expressive style depends on the interaction he wishes to cultivate with the people around him, with whom he lives and relates to. Also, by virtue of being an artist, his sensitivity makes him aware of the presentness of the past. This makes him conscious of a certain kind of 'tyranny of the past' from which he tries to extricate himself by accepting the past as unalterable and true and attempting to modify it in the imaginary world he creates. Myth is thus a palpable presence for the playwright who experiments with it within his genre by relating, interpreting, revisioning and re-fashioning it within the structural framework of his art.

To some extent, modern man's worldly sophistication might have severed him from myths, but his primitive - perhaps congenital -interest in listening to stories has not waned; he has not been weaned off from the primary instinct of asking 'what then?' Both Forster (138) and Yeats (347-48) use the words "and then" and "what then"15 for different purposes; but both of them accept the implications of those words in the narrative process. Man's quest for knowledge and his unfailing interest in stories cater to a primeval desire to communicate concepts and ideas that often defy simple explanations. One is strongly reminded of Shaw's ideas regarding the origin of drama (144). 
Impact Factor: 4.845(SJIF) Research Journal Of English (RJOE) Vol-5, Issue-2, 2020

www.rioe.org.in An International Peer-Reviewed English Journal

ISSN: 2456-2696

Indexed in: International Citation Indexing (ICI), International Scientific Indexing (ISI), Directory of Research Journal Indexing (DRJI) Google Scholar \& Cosmos.

Invariably, the writer (poet/author/playwright) becomes the 'ancient mariner' capable of holding the hurrying wedding guest spellbound by his art of weaving a tale!

Karnad once explained to me in an interview that since he felt incapable of inventing stories, he drew his plots from history, folklore, myths and legends. Indeed, all his plays derive from pre-existing material, yet, like Shakespeare, he transforms the raw material into a unique drama of human emotions and feelings.

But we cannot deny that his translation is very much approximate to the original. In his triology Karnad has raised several basic questions related to the crisis of human values in the society. Individual's relation with individual, family, society and state has been tasted. In Naga Mandala the relationship between Rani and Appanna is typical one. This play has successfully depicted that Rani is acceptable either as a slave by her husband or as a 'whore' by society or as a goddess by her husband and society both, but not as a human being. So numerous questions, related to her, raise the issue of crisis of human values. According to Kurudavva, Appanna "keeps his wife locked up like a caged bird" (Tliree Plays, p. 30). Appanna spends his night and day with a 'harlot' (p. 29). It Is a burning problem of faithlessness of a husband towards his wife. While "there is no one to talk to" Rani (31), Appanna enjoys his time with the prostitute. Rani cannot laugh or even weep. She is "bored to death" (p. 31). Indirectly, Karnad has hinted at the condition of millions of housewives in India who spend their entire life surrounded by four walls and do what they are asked to do. In their life there is no herbal 'root', as in case of Rani, to try on their husbands. They get joy out of trifles of their life. In case of Rani even these trifles are absent. It is only the unbelievable magic love of the Cobra that keeps Rani's life going on.

In HayavadanaKarnad creates a different female character in Padmini. Her husband Devadatta is a learned and intellectual young man. But Padmini is not completely satisfied with him. She is attracted by powerful body of Kapila, the son of a blacksmith and close friend of her husband Devadatta. Her split personality indicates her possessive nature. When Devadatta and Kapila both chop their heads in the Kali temple and the head of Devadatta is jointed on the body of Kapila and that of Kapila on Devadatta's body, Padmini accepts the earlier one as her husband. She feels satisfied after getting the body of Kapila and head of Devadatta in one. Her remark is full of joy when she says: "Fabulous body fabulous brain fabulous Devadatta" (Three Plays, p. 113). When her baby is born, Padmini's wish is that he should be brought up in the forest for few years and then he should be sent to Devadatta's father Vidyasagar.

Her plan is that her son should have a healthy body and a brilliant mind together. She wants to develop him as a child of her own dream. This nature of Padmini indicates her possessive nature as she tries to impose her own wishes on the child for her wish fulfilment. When we think of the son of Padmini and the example of Hayavadan, who is also a 
Impact Factor: 4.845(SJIF) Research Journal Of English (RJOE) Vol-5, Issue-2, 2020

www.rjoe.org.in An International Peer-Reviewed English Journal

ISSN: 2456-2696

Indexed in: International Citation Indexing (ICI), International Scientific Indexing (ISI), Directory of Research Journal Indexing (DRJI) Google Scholar \& Cosmos.

neglected child, we remember the remarks of Bhagawan Shree Rajneesh who says that the problem lies in the lack of sensitivity in the parents.

He says that "we enjoy sex and the child drops in, in between"21 (From Sex to Superconscious, p. 152). What can we expect from such unwelcome and accidental children? Such a child, who is deprived of affection and proper care, gives to the society what he receives from her. Such children feel themselves alienated. Hayavadan, bearing the head of a horse and body of a man is unable to identifyhimself. He does not find any place and role in the society. He wants to take "interest in the social life of the Nation" (Three Plays, p. 81) but he has no society of his own, for he is not a complete man. The Bhagavata blesses him that he may "become successful" in his "search for completeness" (Three Plays, p. 82) but this search is never complete. So such individuals, for whom there is no place in the society and who fight their own way all alone, seldom bother about society when they get success in their life. If some young man like Kappanna bears the responsibility of his blind mother Kuruddava like Srawan Kumar, he is praised by the society, but if he is attracted towards a dream girl he is declared mad. Such quick changes in attitudes of the society indicates some elements of deterioration in it. So the value system is also at flux. J. Krishnamurti has remarked that :

Society is always in a state of degeneration. There is no perfect society. The perfect society may exist in theory, but not in actuality...

(Commentaries of living, p. 32)

If society cannot be perfect, how can we expect perfection from an individual. In such a society we are bound to face crisis of human and social values. It is because, in such societies, says J. Krishnamuri:

... from the biggest politician to the village manipulator, from the highest prelate to the local* priest, from the greatest social reformer to the worn out social worker, each one is using the country, the poor, or the name of God, as a means of fulfilling his ideas, his hopes, his Utopias. He is the centre, 'his' is the power and glory but always in the name of the people, in the name of the holy, in the name of downtrodden... ${ }^{22}$

(Commentaries on Living, p. 32)

But what are the causes that lead to such condition? Perhaps the lack of human values (including social, moral, religious and spiritual values) lies deep as the root cause. Gordon Childe also hints at the same point when he writes that:

...Without such spiritual equipment not only do societies tend to disintegrate, but the individual composing them may just stop bothering to keep alive...

(What Happened in History, p. 22) 
Impact Factor: 4.845(SJIF) Research Journal Of English (RJOE) Vol-5, Issue-2, 2020

www.rioe.org.in An International Peer-Reviewed English Journal

ISSN: 2456-2696

Indexed in: International Citation Indexing (ICI), International Scientific Indexing (ISI), Directory of Research Journal Indexing (DRJI) Google Scholar \& Cosmos.

So, the crisis of values has a fatal and almost suicidal impact on society.

In Karnad's Tughlaq we find all these symptoms of disintegration of the society. The head of the state is unable to check it. He has lost almost all feelings related to human values. He wants to create his own Utopia. For him his dream comes first. It must be fulfilled, no matter how many sacrifices are to be made for it. The Sultan, who should take care of the public welfare, gives an order to shift his capital from Delhi to Daulatabad and every citizen has to obey the command. How many sick, weak and old men and women or young children suffer and die on the way is not a matter of concern for the Sultan. For him power, success and authority is everything and he has to achieve it at any cost. He himself prepares plots for murder to secure his crown. When Muhammad's-step mother says that the kingdom has turned into "a kitchen of death" and asks him if he has his "share of futile deaths", Muhammad shouts: No, they were not futile. They gave me what I wanted-power, strength to shape my thoughts, strength to act, strength to recognise myself...

(Three Plays, p. 204)

If this is the reply of the Sultan, who can save his Kingdom? Karnad has hinted at the history of partition of India, when leaders divided the country and threw it in violence and bloodshed to acquire power, strength, recognition and post. But this disintegration is, as Gordon Childe has hinted, fatal and suicidal to both, the individual (king) and the society (kingdom). In Tughlaq it is evident when Muhammad himself is caught in the same trap. When Barani suggests him to retire from his throne, Muhammad replies:

... I have often thought of that myself to give up this futile seesaw struggle and go to Macca. Sit here by the Kabba and search for the peace Daulatabad has not given me, what bliss! But it isn't that easy. It isn't as leaving the patient in the wilderness because there is no cure for his disease. Don't you see this patient, sacked by fever and crazed by the fear of the enveloping vultures can't be separated from me? I cold have done something if the vultures weren't so close...

(Three Plays, p. 196)

This is what happens to a kingdom and king when human values are lost in the society. Muhammad himself has turned his empire into a desert and is afraid of the vultures that reel above him.

Now, what are the reasons for such crisis of human values in any society? Sometimes it is due to dominance of animal passion. Even Mahatma Gandhi has realised harmful impact of animal passion. Referring to a moment of crisis in his life, Mahatma Gandhi remembers the night when his father died. Just before the death of his father Mahatma Gandhi was massaging him. He was relieved by his uncle few minutes before the death took place. Mahatma Gandhi says that he was very 'glad' and went straight to his "bedroom". His wife, the "poor thing" was sleeping. But he "woke her up". In five or six minutes there was a knock at the door and the servant informed that the father was no more. Here Mahatma Gandhi writes in his 'Experiment' with 'Truth' :So all was over ! I had but to wring my 
Impact Factor: 4.845(SJIF) Research Journal Of English (RJOE) Vol-5, Issue-2, 2020

www.rjoe.org.in An International Peer-Reviewed English Journal

ISSN: 2456-2696

Indexed in: International Citation Indexing (ICI), International Scientific Indexing (ISI), Directory of Research Journal Indexing (DRJI) Google Scholar \& Cosmos.

hands. I felt deeply ashamed and miserable. I ran to my father's room. I saw that if animal passion had not blinded me, I should have been spared the torture of separation from my father during his last moments. I should have been massaging him, and he would have died in my arms...

(An Autobiography, p. 126)

But how many of us have this courage of M.K. Gandhi to accept our sense of guilt and to repent for it? In Naga Mandala, Appanna is dominated by similar 'animal passion'. He devotes his entire day and night to the prostitute. But there is no sense of guilt or remorse in his mind. Here lies the tragedy of the modern man.

Another reason for crisis of human values lies in the formation of what A.K. Ramanujan calls "Western-style nuclear families with their 2:2 children"23, (Introduction; Folktales from India, p. XIII). Such nuclear families are the results of the same disintegration. Certain human values such as sense of help, service, sacrifice and cooperation, which get their birth in and are nourished by joint families, are unknown to nuclear families. In Hayavadan there is no one to take proper care of the children. Hayavadan is left alone after the dispute between his parents. Similarly, the child of Padmini is also left alone in the end. They are deprived of the love and affection that a child gets in a joint family. What can we expect from such children who are doomed to-be alienated just after their birth?

One more reason for the crisis of human values is that our country is passing through process of industrialisation and is still a developing country. Industrialisation has dehumanised the man. Man working with machines, spending most of his time in factories and industrial plants has been gradually dehumanised. His main thrust is on production. He never bothers about the means through which the production is achieved. He can destroy greenary of forrest to get coal. He can turn the Ganges and the Yamuna into sewage. He can cut throat of fellow being for a small piece of land or for a few hundred rupees or to satisfy his animal appetite. He will get, what he wants to possess at any cost. In Hayavadan Padmini gets what she wants to possess, i.e., the head of Devadatta and the body of Kapila. Their sacrifice is not a sacrifice before mother Kali (because the temple is abandoned) but before the possessive power of Padmini who has a strong hold over the life of both the friends. In Naga Mandala, Appanna does not allow Rani even to talk to anybody. He wants to possess her as a material property. In Tughlaq, Muhammad wants to get power, authority and name at any cost.

Unfortunately, most of the Indian writers in English have not delved deep into the social structure to deal with humanitarian problems faced by the untouchables, weaker section of the society, poor farmers, lower middle-class families and working women. Few women writers and feminists have drawn attention toward the problems related to women but they lack complete sincerity in dealing with their problems. Some women writers refer to their sufferings as a girl child and as a bride in their autobiographies but become silent 
Impact Factor: 4.845(SJIF) Research Journal Of English (RJOE) Vol-5, Issue-2, 2020

www.rioe.org.in An International Peer-Reviewed English Journal

ISSN: 2456-2696

Indexed in: International Citation Indexing (ICI), International Scientific Indexing (ISI), Directory of Research Journal Indexing (DRJI) Google Scholar \& Cosmos.

about their own role as a torturing mother-in-law and stop their autobiographies in the midway. No woman writer has raised her voice against the growing tendency of getting a girl child aborted.

Similar is the case with most of the Indian writers in English. Though I agree with $\mathrm{K}$ R. Srinivasa Ayenger that "Indian writing in English is one of the voices in which India speaks", I do not agree with his view that "it is as much Indian as the others" ('Introduction' to Indian Writing in English, p. 3). I am of the opinion that Indian writings in regional languages are far more superior to Indian writing in English. The reasons are obvious. Indian writers in English have not shown sincere efforts for understanding Indian theory of poetics or Indian myths and culture properly. Indian writers in regional languages have deep-rooted experience in understanding socio-economic and cultural problems of the society and deal with the theme of human values in a better way.

\section{Conclusion:}

Girish Karnad has successfully dealt with the theme of crisis in human values in society. It is because what researcher feel, his plays are his own translations of original Kannad versions. But Karnad is unable to provide any solution to these problems. All of three plays in the Triology are unable to give any solution. In Naga Mandala, Appanna is back to Rani owing to fear that she is a goddess. We do not know what will happen to him in future and will he love her in fear or worship her? In Hayavadan, the child is left alone and we do not know the fate he is going to meet. In Tughlaq, Muhammad opens his eyes and "looks around dazed and frightened as though he cannot comprehend where he is" (Three Plays, p. 221). So, almost all plays by Karnad are open ended and the riddle of man is not solved. Rather, he presents a sense of shock and fear about the future because we notice in Naga Mandala that there are herbal roots that can change the venom of a Cobra into love but there is none that can change the brutal and poisonous mind and heart of man.

\section{References:}

- Iyengar, K.R.S., 1985, Indian Writing in English, New Delhi: Sterling Publishers.

- Naik, M.K., 1984, Dimensions of Indian English Literature, New Delhi: SterlingPublishers.

- Ghosh, S., 1986, Rabindranath Tagore, New Delhi: Sahitya Akademi.

- Das, S.K., 1991, A History of Indian Literature, Vol. VIII, New Delhi: Sahitya ○ Akademi.

- Reddy, D.J.P.N., 1994, Literary Spectrum, New Delhi: Arnold Associates.

- Iyengar, K.R.S., The Adventure of Criticism, London: Asia Publishers.

- Rama, K.P. (ed.), 1992, Critical Interactions, Jaipur: Pointer Publishers. 
Impact Factor: 4.845(SJIF) Research Journal Of English (RJOE) Vol-5, Issue-2, 2020

www.rioe.org.in An International Peer-Reviewed English Journal

ISSN: 2456-2696

Indexed in: International Citation Indexing (ICI), International Scientific Indexing (ISI), Directory of Research Journal Indexing (DRJI) Google Scholar \& Cosmos.

- Iyengar. K.R.SIndian Writing in English. 4th cd.. New Delhi St Publishers Pvt. Ltd.. 1984

- Karnad, Girish: Hayavadana. Calcutta: Oxford University Press. 197 subsequent references are to this edition).

- Kumar, Satish:A Survey of Indian English Drama Bareilly: Prakash Depot, 1993.

- Kurtkoti. KirtinathHayavadana. Introduction, Calcutta Oxford Univt Press, 1975

- Naik, M..K. and Punekar, Mokashi: Perspectives on Indian Dram English, Madras: Oxford University Press, 1977.

- Caudwell, Christopher. Illusion and Reality. Delhi: People's Publishing House Ltd, 1956.

- Fluget, J.C. Man, Morals, and Society. Harmondsworth. Penguin Books, 1962.

- Forster, E.M. "Scott," Modern Essays in Criticism. Ed A.S.Cairncross.London:

- Macmillan, 1967. Jung. C.G. Modern Man in Search of a Soul. London: Rutledge\& Kegan Paul, 1962.

- Karnad. Girish. Hayavadana. Calcutta: Oxford Univ Press, 1975, 1988. Nagamandala. Delhi: Oxford Univ Press, 1990.

- Iyengar, K.R. Srinivasa, Indian Writing in English, Sterling Publishing Private Limited, New Delhi, 1962.

- Childe, Gordon, What Happened in History, Penguin Books, 1942. Deyev, Valery, Philosophy and Social Theory; An Introduction to Historical Materialism, Progress Publishers, Moscow, 1987. 